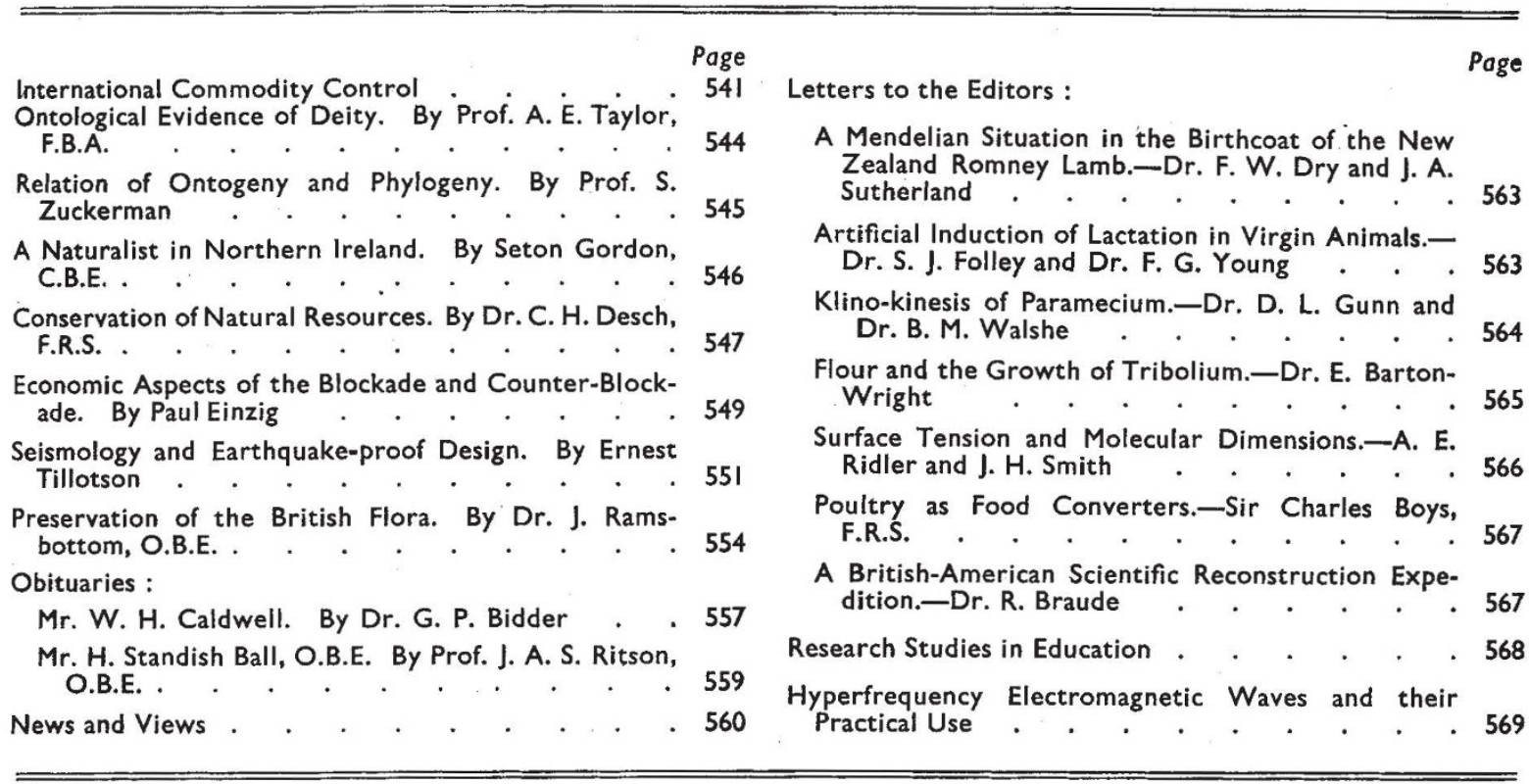

\title{
INTERNATIONAL COMMODITY CONTROL
}

$\mathrm{T}$ HE second Inter-Allied meeting, held at St. James's Palace on September 24, fully justified the hope expressed by Mr. Eden at the conclusion of the first, held on June 12, that the meeting might represent the inauguration of a new phase by which peace will be maintained after victory. This second meeting indeed owes its chief significance, not to the accession of the Soviet Union to its counsels or to the adhesion of the Allied Governments to the common principles of policy set forth in the Atlantic Charter, affirmed at the meeting, important as these may be, but rather to the agreement on concerted action for reprovisioning Europe after defeat of the Nazi regime. That agreement, together with the support and interest of the United States indicated in the statement Mr. Eden was authorized to make on its behalf at the meeting, afford weighty evidence that this time the United States and the individual allies will collaborate in the peace after the war has been won. The importance of American collaboration was indeed confirmed very emphatically by $\mathrm{Mr}$. Sumner Welles in a speech delivered on October 5, in which he discussed the urgent need for plans for reconstruction and condemned the policy of restricted trade followed by the United States during the period between 1918 and the outbreak of the War.
The resolution adopted by the meeting affirmed the common aim of the Governments represented to secure that supplies of food, raw materials and articles of prime necessity should be made available for the post-war needs of the countries liberated from Nazi oppression. It contemplates the coordination of the efforts of the individual Govern. ments on behalf of their own peoples, and pledges the Allied Governments and authorities to prepare the requisite estimates of kinds and amounts, and to indicate the order of priority in which delivery of the supplies is desired. Plans for the most efficient use of individual and Allied shipping resources are also envisaged, and as a first step the resolution proposes the establishment in the United Kingdom of a bureau with which the Allied Governments and authorities would collaborate in framing estimates of their requirements, and which, after collating and co-ordinating these estimates, would present proposals to a committee of Allied representatives under the chairmanship of $\mathrm{Sir}$ Frederick Leith-Ross.

In proposing this resolution, which implements the policy set out in the fourth, fifth and sixth points of the Atlantic Charter, Mr. Eden referred to preliminary work which has already been carried out under the British Government. In addition to the Leith-Ross Committee, a Ministerial Committee 
on Export Surpluses has been established, of which the Minister without Portfolio is chairman. While these Committees have been in the main concerned with the arrangement of purchases, mostly within the British Empire, of commodities which have become surplus to current demand, and primarily to stabilize the economics of the territories concerned, they have been mindful of the value of such purchases as a potential relief store for the European peoples at present being ruthlessly denuded by Germany, and have also started inquiries as to probable human needs.

The framing and co-ordination of estimates of probable requirements is the first task, and the proposal for the establishment of a central bureau is intended to co-ordinate such estimates and provide a practical working approach to a survey of all needs on a common basis. Mr. Eden stated further that the Ministry of War Transport has already been considering what shipping might be available, and the proposed declaration on shipping policy is evidence that the mistake made in 1918 in abandoning immediately after the Armistice the Inter-Allied Food Council and the Allied Maritime Transport Council is unlikely to be repeated.

These developments hold real promise of the establishment of the effective central authority which is essential, and that the international co-operation in the economic field during the crucial period when 'first aid' is required will be built so far as possible out of organizations existing before the armistice. Nevertheless, the more distant horizon is beset with greater difficulties, which even now must be faced if long-range planning to meet such needs is to be possible. A successful attempt to discover means to overcome such difficulties may well depend on an early discovery of the best path to follow.

These reasons give pertinence and urgency to the plans outlined by Mr. Eden, as well as to a number of discussions of various phases of the subject which have recently been opened. Some attention to these problems was given at the recent British Association Conference on "Science and World Order", notably in Sir John Russell's brilliant paper on restoring the scorched earth and in Mr. W. L. Kelly's exposition of the ideals developed in Australia on the disposal of gluts of food as a remedy for trade depression. They have also received attention in Mr. F. L. McDougall's paper on "Empire Primary Products in Relation to Post-War Reconstruction", read before the Royal Society of Arts, and they are analysed in some detail in a P E P broadsheet on commodity control schemes.

Mr. McDougall, after reviewing the failure to improve economic conditions which led to the consideration by the League of Nations of the relation of nutrition to health, agriculture and economic policy, emphasized once more the futility of the Dominions concentrating upon economic national. ism. Reliance upon their own local markets offers no solution, and he suggested that in the word 'welfare' we might find the right and possibly the only solution of post-war economic problems. The Empire primary producer is vitally concerned in the third freedom of President Rooseveltfreedom from want everywhere in the world. $\mathrm{He}$ is directly concerned with food and raw materials of clothing, and his own vital interests require accordingly an economic policy in all countries directed towards higher standards of nutrition, housing, clothing and other factors of social welfare.

If at the same time we succeed in translating into action President Roosevelt's fourth freedomfreedom from war-with what it involves in relief from expenditure on armaments, Mr. MeDougall believes that the nations would be able to devote a larger proportion of their resources to social welfare. He suggested indeed that the industrial nations will find that they cannot afford not to put a rising standard of living in the forefront of economic policy; and he pointed out that in India and in most of the British Colonies the internal problem also demands the reorientation of agriculture designed to secure plentiful supplies of healthgiving food to the producers themselves.

Mr. McDougall's paper was delivered a considerable time before the historic meeting of Mr. Churchill and President Roosevelt, and is of particular interest as indicating the way in which opinion in the Dominions already recognizes its vital interest in the vision and policy of a Pax oceanica opened up in the Atlantic Charter. The Pax oceanica can no longer be maintained by Great Britain alone, and not the least significant feature of the Atlantic Charter is the evidence it affords that the United States is completing her evolution from a continental into an oceanic power. The Dominions are vitally interested in maintaining the Pax oceanica as the basis of world order and freedom, and it is clear that they are ready to recog. nize not merely this obligation, but also that it can only be pursued in relation to Continental Europe. The economic expansion of the Dominions can only be achieved through the raising of standards of living, which is a world-wide problem.

A policy tending towards the creation or recreation of world markets, whether by developing the welfare of the Colonial peoples or by European reconstruction, involves co-operation in the creation of markets. It means making the consumer and not the producer the starting-point of policy; the organization of consumption takes precedence over the organization of production. The old 
programme of freedom of trade is transformed into a new programme of freedom from want.

The policy of direct attack upon economic stagnation and social backwardness in the Colonies, like the idea of minimum standards in nutrition, health, social services and education stressed by Dr. Julian Huxley in "Democracy Marches", involves a new approach to commodity control schemes. As the P E P broadsheet shows, the existing schemes all imply some degree of conscious planning and co-ordination of action, and their development has been in the hands of pioneers whose ability and honesty of purpose have both varied. Even during the War, great advances are being made in the technique of economic control, and education in the uses and limits of control is being widely diffused. Much is being learnt from the almost world-wide application of 'lease-lend' procedure and the working out of shipping programmes for essential supplies, while the significance of organized research and planning in this field under Sir Frederick Leith-Ross is far-reaching.

The P E P broadsheet gives a concise analysis of the commodity schemes already in existence, their characteristic features and actual results achieved during the last twenty years. This analysis is inevitably much slighter than that in the report of the League of Nations committee for the study of the problem of raw materials, or in the Royal Institute of International Affairs information paper on raw materials and colonies. The most valuable feature of the broadsheet is accordingly its discussion of the purpose of commodity control and of the methods of establishing it, based upon the conclusions drawn from experience already available.

Despite the inherent disadvantages of commodity schemes and the frequent abuse of monopoly power, there can be no doubt that control has come to stay. Without its continuance, problems involved in the handling of world commodities by international co-operation after the War cannot be solved. Functional, as distinct from. geographical or national, organizations are likely to play an increasingly important part in economic life, and it is important to learn the utmost from mistakes in the past, so that such functional bodies can be made fully accountable to the community as a whole by a strengthening of political authority-national and international. The commodity control scheme of the future, international in its control of supply and of markets, should be subject to public supervision and allow for a substantial representation of consumers.

This development should remove the two main criticisms levelled against past restriction schemes - the maintenance of prices at an unreasonably high level, and the persistence of inefficient production under restriction schemes. The measures now being taken to deal with the problem of surpluses, however, involve further problems. The holding of stocks on a commodity control basis affects the financial issue. Some means must be found of bringing finance into line if commodity control schemes are to function satisfactorily in the post-war period.

Now that Governments have entered the market as large-scale buyers, they are likely to continue to do so after the War, both for unwanted surpluses and for key raw materials and foodstuffs. One centralized Government organization which controlled the marketing of such products would be in a stronger selling position than a number of individual producers and mechants, and would also be able to ensure fair distribution. In schemes established after the War for commodities in which there are shortages, consumer interest will undoubtedly play a much more important part. So, too, the barter arrangement between the United States and the British Government holds possibilities for development in the post-war period, the main economic task of which will be to build up a system which is not subject to the violent fluctuations characteristic of the period 1920-39, but which stimulates a steady expansion of economic activity and makes adjustments possible with the least dislocation of economic life.

This task is parallel with the political task of building up a stable world order which fosters cooperation between nations. Control of the production and marketing of raw materials, if organized on a comprehensive international basis, is of the first importance in both tasks. Moreover, commodity control in such an economic order involves not merely eliminating past defects so as to make a reformed pattern of commodity control an accepted part of the economic structure. It involves also market surveys and forecasting of a comprehensive type, which are scarcely possible save under a strongly organized international scheme. It requires, too, a concerted effort to avoid the existence of surpluses of foodstuffs and raw materials at one point and shortages at another, which under commodity schemes before the War were frequently found in neighbouring countries. It involves also control over the industrial potential of every nation and therefore over its power to pursue policies of aggression, and the steady and continuous enforcement of peaceful measures rather than occasional belated attempts to stop wars.

Recognition of the economic and political objects of post-war-commodity control leads Political and Economic Planning to suggest the formation of an international raw materials union for all commodities, built up on the lines of the International 
Postal Union and affiliating the international and national associations controlling particular commodities. This union could be set up in the first instance by the Governments of the Allies 'and of the United States as a non-political body, the chief concern of which would be to promote economic welfare. Only key raw materials would be brought in at the start, and the union would not concern itself with particular commodities but with the general structure to be adopted in particular commodity control schemes and the terms of supply and of purchase to be observed by bodies affiliated to it.

One important function of the suggested union would be the publication of regular reports analysing trends in price and consumption of controlled commodities, indicating successful innovations for adoption elsewhere and defects to be avoided in future schemes. Common services, such as technical and economic research or exchange of personnel, would be organized by the various commodity controls for their own commodities, and by the union in respect of wider interests. The union would also promote co-ordination between the various commodity schemes in neighbouring groups of territories, for example, by creating regional reserve stocks, developing storage capacity, encouraging diversification in areas too dependent on one or a few products, and assisting exchanges of surpluses.

On the further question of the function of such a union in enforcing economic sanctions, the broadsheet merely indicates the possibilities, with a pointed reference to the measures which the United States and the British Commonwealth are belatedly taking against Japanese aggression. The suggestion is indeed too tentative to be judged in detail, but it does indicate the value of establishing some such union during the War, and the way in which it could facilitate the work of the International Reconstruction Commission which will assuredly be required afterwards in place of the unco-ordinated effects of individual Governments which proved so ineffective twenty years ago. The same basic idea has been outlined by Dr. Julian Huxley in "Democracy Marches", and it is implicit in the fourth and fifth points of the Atlantic Charter. No reader of the P E P broadsheet can remain unaware of the difficulties with which this problem bristles, but that they should be stated clearly and thoroughly discussed is the first step, not merely towards meeting immediate needs, but also to the long-term planning and cooperation upon which the reconstruction of world trade and the development of a new and more stable world order depend.

\section{ONTOLOGICAL EVIDENCE OF DEITY}

Mind and Deity

Being the Second Series of a Course of Gifford Lectures on the General Subject of Metaphysics and Theism given in the University of Glasgow in 1940. By Dr. John Laird. Pp. 322. (London: George Allen and Unwin, Ltd., 1941.) 10s. 6d. net.

$\mathrm{P}$ ROF. LAIRD gives us here the second half of his recent Gifford Lectures (the first half having already been published under the title "Theism and Cosmology"). "Theism and Cosmology" was exclusively concerned with the two types of theistic proof "which appeal more directly to the scientific mind", the "cosmological argument" for a "great first cause", and the argument from design. The centre of interest in the present volume is different; we are concerned with the "ontological proof", which if valid would show that God's existence cannot be denied without flagrant selfcontradiction, and the various forms of the "moral argument". The consideration of the latter leads to much interesting discussion of the sense in which omnipotence, benevolence, personality can be ascribed to God, and of the possibility of "pantheism". The conclusion of the whole matter reached in the final paragraphs is that while none of the theistic "proofs" is convincing or even highly plausible, theism is a tenable, though not demonstrably true, metaphysical theory of the universe which is more plausible than most of the possible alternatives. The verdict is the Scots "not proven" (which, by the way, commonly means that the jury knows pretty well what to think of the case). This finding will not satisfy all philosophical theists, though it should not perturb those of them who are Christians, familiar with the thought of faith as a venture, an assent of the mind to what is not forced on it by demonstration.

Few readers of NATURE will be likely to quarrel with the contention that the "ontological proof", whether in Anselm's version or in Descartes', is a fallacy which has been once for all exposed by Kant, and that its pretended resuscitation by Hegel is really a substitution of assertion for proof. I am not equally convinced by the reasoning of the chapters on "Value and Existence" and "The Moral Proofs of Theism". Prof. Laird is always fair-minded, 